DOI : https://doi.org/10.24843/JFU.2020.v09.i01.p04

pISSN: 2301-7716; eISSN: 2622-4607

Jurnal Farmasi Udayana, Vol 9, No 1, Tahun 2020, 26-30

\title{
Evaluasi Efektivitas Biaya Penggunaan Terapi \\ Kombinasi Obat Antidiabetes-Antihipertensi pada Pasien Diabetes Mellitus Tipe 2 dengan Hipertensi di RSUP Sanglah
}

\author{
Warnaya, P.C.I. ${ }^{1}$, P.B.P.P. Budiartha ${ }^{1}$, N.N.S.M. Arwanawati ${ }^{1}$, M.A. Sarasmita ${ }^{1}$ \\ ${ }^{1}$ Program Studi Farmasi Fakultas Matematika dan Ilmu Pengetahuan Alam Universitas Udayana, Jalan Kampus \\ Unud, Jimbaran, 80364 \\ E-mail: ciaintana17@gmail.com
}

Riwayat artikel: Dikirim: 07/04/2020; Diterima: 30/04/2020, Diterbitkan: 25/06/2020

\begin{abstract}
Infectious diseases have been shifted by degenerative metabolic diseases. Metabolic disease whose prevalence tends to increase is type 2 diabetes mellitus characterized by decreased insulin secretion due to insulin retention which interferes with pancreatic beta cell function, which if not handled properly will result in chronic complications. The most common complication of diabetes is hypertension, which is around $54.2 \%$. Patients with diabetes mellitus and hypertension must take life-long therapy. This will have an impact on patient costs. In addition, the use of drug therapy for diabetes mellitus can be given with several different combinations, so the costs and outcomes of the therapy produced also vary. The varied use of drug therapy results in differences in the costs and outcomes of the therapy. Based on the results of research that has been done, the calculation of Average Cost Effectiveness Ratio (ACER) and Incremental Cost Effectiveness Ratio (ICER) shows that the most cost-effective therapeutic option is the use of antidiabetic therapy combinations of insulin sensitivity enhancers with long-acting insulin and antihypertensive groups CCB (Calcium Channel Blocker). Therefore, it can be concluded that the combination therapy of antidiabetic and antihypertensive with the most cost effectiveness based on ACER and ICER values is a combination of antidiabetic drug groups that increase insulin sensitivity and long-acting insulin with antihypertensive CCB.
\end{abstract}

Keywords: Type 2 Diabetes Mellitus, Hypertension, ACER, ICER

Penyakit infeksi telah digeser oleh penyakit metabolik degeneratif. Penyakit metabolik yang prevalensinya cenderung meningkat adalah diabetes mellitus tipe 2 yang dikarakterisasi oleh sekresi insulin yang menurun akibat retensi insulin yang mengganggu fungsi sel beta pankreas, dimana jika tidak ditangani dengan tepat akan mengakibatkan komplikasi kronis. Komplikasi diabetes terbanyak adalah hipertensi yaitu sekitar 54,2\%. Pasien diabetes mellitus dan hipertensi harus melakukan terapi seumur hidup. Hal ini akan berdampak pada biaya yang harus dikeluarkan pasien. Selain itu, penggunaan terapi obat diabetes mellitus dapat diberikan dengan beberapa kombinasi yang berbeda, sehingga biaya dan luaran terapi yang dihasilkan juga bervariasi. Bervariasinya penggunaan terapi obat menyebabkan timbulnya perbedaan dalam pengeluaran biaya dan luaran terapinya. Berdasarkan hasil penelitian yang telah dilakukan, hasil perhitungan Average Cost Effectiveness Ratio (ACER) dan Incremental Cost Effectiveness Ratio (ICER) menunjukkan bahwa pilihan terapi yang paling cost effectiveness adalah penggunaan golongan terapi antidiabetes kombinasi peningkat sensitifitas terhadap insulin dengan long-acting insulin dan antihipertensi golongan CCB (Calcium Channel Blocker). Maka dari itu dapat disimpulkan bahwa terapi kombinasi antidiabetes dan antihipertensi yang paling efektif terhadap biaya berdasarkan nilai ACER dan ICER adalah kombinasi golongan obat antidiabetes peningkat sensitivitas terhadap insulin dan long-acting insulin dengan antihipertensi CCB.

Kata kunci: Diabetes Mellitus Tipe 2, Hipertensi, ACER, ICER.

\section{PENDAHULUAN}

Penyakit infeksi telah digeser oleh penyakit metabolik degeneratif. Penyakit metabolik yang prevalensinya cenderung meningkat adalah diabetes mellitus. Saat ini prevalensi Diabetes Mellitus (DM) semakin meningkat di Indonesia. Prediksi WHO, di Indonesia penderita DM 
mencapai 21,3 juta orang pada tahun 2030 (Pramestiningtyas dkk., 2014; Perkeni, 2015). Diabetes mellitus diakibatkan karena insulin yang diproduksi oleh pankreas tidak dapat memenuhi kebutuhan tubuh atau dapat pula disebabkan oleh insulin yang diproduksi tidak digunakan secara efektif (Dinaryanti dkk., 2012). Berdasarkan penelitian yang telah dilakukan oleh Yuliani dkk (2014) penderita DM tipe 2 lebih dari $90 \%$. Diabetes mellitus tipe 2 dikarakterisasi oleh sekresi insulin yang menurun akibat retensi insulin yang mengganggu fungsi sel beta pankreas, dimana jika tidak ditangani dengan tepat akan mengakibatkan komplikasi kronis (Yuliani dkk., 2014). Komplikasi kronis merupakan kondisi munculnya dua atau lebih penyakit.

Klub Persadia Rumah Sakit Islam Jakarta Pondok Kopi pada tahun 1998 hingga 2005 menyebutkan bahwa komplikasi diabetes terbanyak adalah hipertensi yaitu sekitar 54,2\% (Rosyada dan Trihandini, 2013). Hipertensi adalah kondisi tekanan darah sistolik (TDS) dan diastolik mencapai $>140 \mathrm{mmHg}$ dan $>90 \mathrm{mmHg}$. Penanganan hipertensi yang tidak tepat menyebabkan terjadinya stroke, congestive heart failure, dan serangan jantung (Rahajeng dan Tuminah, 2009). Penanganan yang tepat terhadap hipertensi pada penderita diabetes melitus adalah dengan mengontrol tekanan darahnya agar $<140 / 80 \mathrm{mmHg}$ yang bertujuan untuk mencegah dampak komplikasi yang lebih serius (Saputri dkk., 2016).

Komplikasi kronis pada penderita diabetes dapat menjadi ancaman buruk karena penggunaan sejumlah obat secara bersamaan yang dapat menyebabkan peningkatan reaksi obat (Rosyada dan Trihandini, 2013). Diabetes mellitus tipe 2 dapat diberikan terapi farmakologi berupa antidiabetik oral atau terapi insulin (Putra dkk., 2017). Terapi antidiabetik oral atau insulin diawali dengan dosis terendah, kemudian ditingkatkan secara bertahap berdasarkan kadar glukosa dalam darah. Efektivitas terapi yang diharapkan dapat dicapai dengan menyesuaikan dosis terapi sesuai dengan kebutuhan (Primadiamanti, 2009). Sedangkan terapi farmakologi untuk hipertensi, golongan ACE-Inhibitor khususnya captopril banyak digunakan sebagai antihipertensi untuk penderita dengan komplikasi diabetes melitus (Ernawati, 2016).

Faktor biaya, kepatuhan, dan kesembuhan pasien dalam mengkonsumsi obat sangat bergantung pada pengobatan yang tepat, sehingga pasien dapat diuntungkan (Pramestiningtyas dkk., 2014). Pasien diabetes mellitus dan hipertensi harus melakukan terapi seumur hidup. Selain itu, penggunaan terapi obat diabetes mellitus dapat diberikan dengan beberapa kombinasi yang berbeda, sehingga biaya dan luaran terapi yang dihasilkan juga tinggi dan bervariasi (Putra dkk., 2017). Berdasarkan uraian di atas, penyakit DM tipe 2 dengan hipertensi merupakan penyakit yang progresif, sehingga biaya yang dikeluarkan pasien akan semakin meningkat. Maka dari itu, evaluasi penggunaan biaya terapi untuk penanganan penderita diabetes melitus tipe 2 dengan hipertensi penting dilakukan untuk mengetahui kombinasi obat yang baik dan memberikan hasil terapi yang paling memuaskan, sehingga dapat meningkatkan angka harapan hidup pasien.

\section{BAHAN DAN METODE}

\section{Bahan dan Alat}

Alat penelitian yang digunakan berupa lembar pengumpul data, alat tulis dan alat hitung. Bahan penelitian terdiri dari rekam medis meliputi identitas pasien, seperti nama, nomor rekam medik, usia, jenis kelamin; Data laboratorium meliputi hasil pemeriksaan kadar $\mathrm{HbA1c}$, dan tekanan darah (TD) dari baseline hingga bulan ke3; Biaya yang dikeluarkan meliputi tarif pengobatan, biaya pemeriksaan dan konsultasi, biaya pemeriksaan laboratorium, dan biaya administrasi dari bagian Instalasi Farmasi RSUP Sanglah.

\section{Metode}

Metode penelitian menggunakan rancangan deskriptif secara non-eksperimental. Data diperoleh secara retrospektif dari baseline hingga bulan ke-3 untuk menilai efektivitas biaya penggunaan terapi kombinasi obat antidiabetesantihipertensi pada pasien diabetes mellitus tipe 2 dengan hipertensi di RSUP Sanglah. Sedangkan, analisis efektivitas biaya dilakukan dengan perspektif pemerintah. 
DOI : https://doi.org/10.24843/JFU.2020.v09.i01.p04

pISSN: 2301-7716; eISSN: 2622-4607

Jurnal Farmasi Udayana, Vol 9, No 1, Tahun 2020, 26-30

\section{HASIL}

Nilai ACER dari beberapa jenis terapi ditampilkan pada Tabel 1, sedangkan nilai ICER dari beberapa jenis terapi ditampilkan pada Tabel 2 .

Tabel 1. Nilai ACER dari Beberapa Jenis Terapi

\begin{tabular}{|c|c|c|c|}
\hline No. & Jenis Terapi & $\begin{array}{l}\text { Total Biaya Medis } \\
\text { Langsung ( } R p)\end{array}$ & ACER \\
\hline \multirow[t]{3}{*}{1.} & Rapid-acting insulin & 726.286 & $32.682,87$ \\
\hline & Long-acting insulin & & \\
\hline & $\mathrm{ARB}$ & & \\
\hline \multirow[t]{4}{*}{2.} & Rapid-acting insulin & 917.286 & $20.638,94$ \\
\hline & Long-acting insulin & & \\
\hline & ARB & & \\
\hline & $\mathrm{CCB}$ & & \\
\hline \multirow[t]{3}{*}{3.} & Insulin Secretagogue & 551.950 & $27.597,5$ \\
\hline & Peningkat sensitivitas terhadap insulin & & \\
\hline & ARB & & \\
\hline \multirow[t]{3}{*}{4.} & Peningkat sensitivitas terhadap insulin & 482.720 & $19.308,8$ \\
\hline & Long-acting insulin & & \\
\hline & CCB & & \\
\hline
\end{tabular}

Keterangan:

ARB : Angiotensin Receptor Blockers

CCB : Calcium Channel Blockers

Tabel 2. Nilai ICER dari Beberapa Jenis Terapi

\begin{tabular}{clccccc}
\hline No. & \multicolumn{1}{c}{ Jenis Terapi } & $\mathrm{C}(\mathrm{Rp})$ & $\mathrm{E}(\%)$ & $\Delta \mathrm{C}(\mathrm{Rp})$ & $\Delta \mathrm{E}(\%)$ & ICER \\
\hline 1. & $\begin{array}{l}\text { Peningkat sensitivitas } \\
\text { terhadap insulin }\end{array}$ & 482.720 & 25 & 482.720 & 25 & $19.308,8$ \\
\hline & Long-acting insulin & & & & \\
\hline & CCB & & & & & \\
\hline Rapid-acting insulin & 917.286 & 44,444 & 434.566 & 19,444 & $22.349,108$ \\
& & & & & & 57 \\
\hline & Long-acting insulin & & & & & \\
\hline & ARB
\end{tabular}

Keterangan:

ARB : Angiotensin Receptor Blockers

CCB : Calcium Channel Blockers

\section{PEMBAHASAN}

Pengambilan data penelitian mengenai cost effectiveness penggunaan terapi kombinasi antidiabetes dengan antihipertensi dilakukan pada pasien rawat jalan di RSUP Sanglah. Jumlah pasien yang memiliki kriteria inklusi dan eksklusi berjumlah 27 pasien yang meliputi 16 pasien perempuan dan 11 pasien laki - laki. Biaya pengobatan yang dianalisis adalah biaya medis langsung yang terdiri dari biaya terapi obat, biaya pemeriksaan dan konsultasi, biaya laboratorium, serta biaya administrasi. Selain itu, penelitian ini menggunakan perspektif pemerintah, karena hasil dari penelitian ini dapat dijadikan acuan oleh pihak RSUP Sanglah untuk mempertimbangkan terapi kombinasi yang paling efektif dari segi biaya pada terapi antidiabetes dan antihipertensi bagi pasien. Penentuan terapi yang efektif dapat dilihat 
berdasarkan penurunan nilai $\mathrm{HbA} 1 \mathrm{c}<7 \%$ dan Berdasarkan data yang telah diperoleh dihasilkan bahwa penggunaan terapi kombinasi antidiabetes kombinasi antidiabetes rapid-acting insulin, long-acting insulin dengan ARB dan CCB adalah kombinasi antidiabetes-antihipertensi yang memiliki efektivitas terapi paling tinggi dibandingkan ketiga terapi kombinasi lainnya. Interpretasi hasil analisis efektifitas biaya pada penelitian ini dilakukan dengan rasio efektifitas yaitu ACER dan ICER. Nilai ACER digunakan untuk membandingkan total biaya terapi pengobatan dibagi dengan luaran klinis untuk menghasilkan biaya yang digunakan untuk membandingkan hasil klinik yang lebih spesifik. Suatu alternatif dikatakan paling cost effectiveness dilihat dari nilai ACER terendah dan semakin tinggi nilai ACER maka alternatif tersebut kurang cost effectiveness. Nilai ACER diperoleh dengan membagi total biaya medis langsung dengan persentase efektifitas terapi. Sedangkan, nilai ICER adalah biaya yang perlu ditambahkan untuk penurunan 1\% kadar HbA1c dan tekanan darah sistolik, sehingga nilai ICER yang digunakan sedapat mungkin bernilai rendah yang menunjukkan biaya tambahan yang dikeluarkan dapat seminimum mungkin.

Berdasarkan data yang telah diperoleh, pilihan terapi yang paling cost effectiveness berdasarkan perhitungan ACER adalah adalah penggunaan golongan terapi antidiabetes kombinasi peningkat sensitifitas terhadap insulin dengan long-acting insulin dan antihipertensi golongan Calcium Channel Blockers (CCB) dengan nilai ACER paling rendah yakni $\mathrm{Rp}$ 19.308,8,-. Sedangkan, penggunaan golongan terapi antidiabetes kombinasi rapid-acting insulin dengan long-acting insulin dan antihipertensi golongan Angiotensin Receptor Blockers (ARB) tergolong terapi pengobatan yang paling tidak efektif biaya, karena nilai ACER yang diperoleh paling tinggi. Pada perhitungan ICER, efektifitas terapi diurutkan dalam tabel dari efektivitas terapi paling rendah hingga tertinggi berdasarkan total biaya medis langsung. Nilai ICER diperoleh biaya sebesar Rp 19.308,8,- pada kombinasi golongan obat antidiabetes peningkat sensitivitas terhadap insulin dan long-acting insulin dengan antihipertensi CCB. tekanan darah sistolik $<140 \mathrm{mmHg}$. Sehingga dapat dikatakan bahwa kombinasi obat antidiabetes dan antihipertensi golongan peningkat sensitivitas terhadap insulin dan longacting insulin dengan antihipertensi $\mathrm{CCB}$ adalah kombinasi yang paling cost effectiveness diantara variasi kombinasi golongan obat lainnya berdasarkan nilai ACER dan ICER.

\section{KESIMPULAN}

Terapi kombinasi antidiabetes dan antihipertensi yang paling efektif biaya berdasarkan nilai ACER dan ICER adalah kombinasi golongan obat antidiabetes peningkat sensitivitas terhadap insulin dan long-acting insulin dengan antihipertensi CCB (Calcium Channel Blocker).

\section{UCAPAN TERIMAKASIH}

Penulis menyampaikan terimakasih kepada instalasi rekam medis RSUP Sanglah serta tim PKM Penelitian Program Studi Farmasi, Fakultas Matematika dan Ilmu Pengetahuan Alam, Universitas Udayana.

\section{DAFTAR PUSTAKA}

American Diabetes Association. 2014. Standard Medical Care in Diabetes. Washington DC: ADA.

Dinaryanti, P., A. Fudholi, dan T.M. Andayani. 2012. Analisis Biaya dan Efektivitas Terapi Pasien Diabetes Melitus Tipe 2 Rawat Jalan di RSUD Sleman Yogyakarta. Jurnal Manajemen dan Pelayanan Farmasi. Vol 2(1): 14-19.

Direktorat Bina Farmasi Komunitas dan Klinik. 2005. Pharmaceutical Care untuk Penyakit Diabetes Mellitus. Jakarta: Departemen Kesehatan Republik Indonesia.

Ennawati, Y. 2016. Analisis Efektifitas Biaya Penggunaan Antihipertensi Kombinasi dua Obat pada Pasien Hipertensi Rawat Jalan di Rumah Sakit "X" pada Tahun 2012. Publikasi Ilmiah. Fakultas Farmasi, Universitas Muhammadiyah, Surakarta.

Hongdiyanto, A., P.V.Y Yamlean, H.S Supriati. 2013. Evaluasi Kerasionalan Pengobatan 
Warnaya dkk.

DOI : https://doi.org/10.24843/JFU.2020.v09.i01.p04

pISSN: 2301-7716; eISSN: 2622-4607

Jurnal Farmasi Udayana, Vol 9, No 1, Tahun 2020, 27-31

Diabetes Mellitus Tipe 2 pada Pasien Rawat Inap di RSUP Prof. dr. R. D. Kandao Manado Tahun 2013. Pharmacon. Vol 3(2):77-86.

Lestari, U., D. Darwin., L. Estiana. 2011. Pola

Pengobatan pada Pasien Hipertensi dengan

Diabetes Mellitus Tipe 2 di RSUD Raden

Mattaher Jambi. Jurnal Sains dan Teknologi

Farmasi. Vol. 16(2): 189-196.

Perkeni. 2015. Konsensus Pengelolaan dan

Pencegahan Diabetes Militus Tipe 2 di

Indonesia. Jakarta: PB Perkeni

Pramestiningtyas, E., S.B. Prihwanto, Wiratmo, D. Holidah, F.A. Fajrin. Analisis Efektivitas Biaya Berdasarkan Nilai ACER Penggunaan Insulin Dibandingkan Kombinasi InsulinMetformin pada Pasien Diabetes Melitus Tipe 2 di Instalasi Rawat Inap RSD dr.Soebandi Jember Periode 2012 [skripsi]. Jember: Universitas Jember

Rahajeng, E., dan S. Tuminah. 2009. Prevalensi Hipertensi dan Determinannya di Indonesia. Majalah Kedokteran Indonesia 59 (12): 580-587.

Rosyada, A. dan I. Trihandini. 2013. Determinan Komplikasi Kronik Diabetes Melitus pada
Lanjut Usia. Jurnal Kesehatan Masyarakat Nasional 7 (9): 395-401.

Sari, B.S., G. Citraningtyas, D.S. Wewengkang. Analisis Efetivitas Biaya (Cost Effectiveness Analysis) pada Pasien Apendisitis di RSU Pancaran Kasih GMIM Manado. Pharmacon Jurnal Ilmiah Farmasi. Vol 6(3): 268-277.

Sastroasmoro, S dan Ismael, S. 2011. Dasar-dasar Metodologi Penelitian Klinis. Jakarta: Binarupa Aksara.

Siahaan, Y. R. 2013. Analisis Rata-rata Total Harga Obat Antihipertensi dan Antidiabetes pada Penderita Hipertensi dan DM Tipe 2 di Rumah Sakit Umum Daerah Sidoarjo Selama Periode Tahun 2011-2012. Jurnal Ilmiah Mahasiswa Universitas Surabaya. Vol 2(2):4-22.

Yuliani, F., F. Oenzil, dan D. Irayani. 2014. Hubungan Berbagai Faktor Resiko Terhadap Kejadian Penyakit Jantung Koroner pada Penderita Diabetes Melitus Tipe 2. Jurnal Kesehatan Andalas 3(1): 3740. 